\title{
Hindlimb protein turnover and muscle protein synthesis in lambs: a comparison of techniques
}

\author{
BY L. A. CROMPTON AND M. A. LOMAX \\ Growth Biochemistry Group, Department of Biochemistry and Physiology, University of Reading, \\ Whiteknights, PO Box 228, Reading, Berkshire RG6 $2 \mathrm{AJ}$
}

(Received 9 May 1991-Accepted 8 May 1992)

\begin{abstract}
A combination of arterio-venous difference, kinetic isotope transfer and blood flow rate techniques were used to measure tyrosine metabolism across hindlimb tissues of nine growing lambs (average live weight $36.5 \mathrm{~kg}$ ) fed on a range of dry matter intakes. Muscle protein synthesis was measured using a continuous infusion technique and compared with simultaneous estimates of hindlimb protein turnover calculated from the values for tyrosine metabolism. When the specific radioactivity (SRA) of tyrosine in the arterial plasma free pool was assumed to be the same as the SRA of tyrosine in the direct precursor pool of protein synthesis, hindlimb protein synthesis $\left(k_{\text {sap }} ; 3.66(\mathrm{SEM} 0.50) \% / d\right)$ was significantly $(P<0-001)$ higher $(68 \%)$ than muscle protein synthesis $\left(k_{s p} ; 2 \cdot 18(\operatorname{SEM~} 0.31) \% / d\right)$ but was similar to the value for muscle protein synthesis calculated using the homogenate free tyrosine SRA $\left(k_{s h} ; 3.35\right.$ (SEM 0.42) \%/d). Hindlimb and muscle protein synthesis $(y)$ were both significantly related to dry matter intake $(x)\left(k_{s a v}\right.$, $\left.r^{2} 0.667, P=0.007 ; k_{\mathrm{sh}}, r^{2} 0.968, P<0.001\right)$ and there was no significant difference between the slopes $(P=0.532)$ and intercepts $(P=0.945)$ of the two regression lines. The results demonstrate that hindlimb protein turnover cannot be quantitatively compared with muscle protein synthesis, probably due to high protein metabolic activity in non-muscular tissues within the hindlimb, although similar responses in protein synthetic rate to the level of feed intake were observed between hindlimb and muscle tissues.
\end{abstract}

Hindlimb protein turnover: Skeletal muscle: Protein synthesis: Lambs

Studies on the hormonal and nutritional regulation of skeletal muscle mass require estimates of the rate of both protein synthesis and degradation. The rate of muscle protein synthesis in vivo has been measured using either a continuous infusion (Garlick et al. 1973) or a flooding dose (Garlick et al. 1980) of tracer amino acid and estimating the incorporation of tracer into tissue protein samples. Muscle protein degradation in vivo is usually calculated indirectly from the difference between the rates of protein synthesis and protein gain. The rate of protein gain in muscle tissue is measured over a period of time by comparative slaughter (e.g. Bohorov et al. 1987), but this measurement is not made simultaneously with protein synthesis and repeated measurements cannot be made in one animal. Measurement of the urinary excretion of 3-methylhistidine has been used as a specific index of muscle protein degradation; however, the technique is invalid in sheep (Harris \& Milne, 1977, 1980) and is still criticized in other species (see Tomas \& Ballard, 1987; Barrett \& Gelfand, 1989).

Previous studies have employed arterio-venous difference techniques to estimate simultaneously limb protein synthesis, degradation and gain in several species by measuring the exchange of an amino acid during a constant infusion of the same isotopically-labelled amino acid. Such studies have used leucine across the human forearm (Cheng et al. 1985, 1987) and sheep hindlimb (Oddy \& Lindsay, 1986; Pell et al. 1986; Oddy et al. 1987), valine across the sheep hindlimb (Teleni et al. 1986), tyrosine across the sheep hindlimb (Vincent, 1984; Crompton, 1990) and cattle hindlimb (Boisclair et al. 1988) and 
phenylalanine across the sheep hindlimb (Oddy et al. 1988; Harris et al. 1989b), dog hindlimb (Barrett et al. 1987) and human forearm (Gelfand \& Barrett, 1987; Thompson et al. 1989).

The values for limb protein synthesis have been reported to be similar to values for muscle protein synthesis (Oddy \& Lindsay, 1986; Halliday et al. 1988) but there have been no studies which have simultaneously compared hindlimb with muscle protein synthesis over a wide range of nutritional intakes. We report a study which demonstrates that the two estimates of protein synthesis (hindlimb and muscle) give similar values across a range of feed intakes in ruminant lambs.

\section{MATERIALS AND METHODS \\ Animals and surgical preparation}

Nine wether lambs (Suffolk $\hat{\sigma} \times($ Bluefaced Leicester $\hat{\jmath} \times$ Swaledale $q$ ) ) ) were housed individually at approximately 18 weeks of age ( $30 \mathrm{~kg}$ live weight), 1 week before surgery and 4 weeks before the experiment. All animals were fed on a diet of a commercial barleybased concentrate (Lamlac Start to Finish; Volac Limited, Orwell, Royston, Herts.) and a medium-quality coarsely-chopped hay $(9: 1, \mathrm{w} / \mathrm{w})$ designed to achieve a growth rate of $350 \mathrm{~g} / \mathrm{d}$ according to the Ministry of Agriculture, Fisheries and Food (1984). The diet was estimated to contain $11.9 \mathrm{MJ}$ metabolizable energy $/ \mathrm{kg}$ dry matter (DM) and $24.4 \mathrm{~g} \mathrm{~N} / \mathrm{kg}$ DM. Animals were fed on their daily ration in two equal portions at 09.30 and 17.00 hours and feed refusals were recorded at 09.25 hours the next day. Animals had free access to water and mineral licks throughout the experiment. In the week before surgery animals were weaned onto the previously mentioned diet and in the 3 weeks post-surgery and before the experiments animals were allowed to recover fully and adapt to their surroundings, handling and the experimental routine.

At 1 week after housing, silicone rubber catheters ('Silastic' medical grade tubing, $0.76 \mathrm{~mm}$ i.d., $1.65 \mathrm{~mm}$ o.d.; Dow Corning Limited, Reading, Berks.) were implanted into the carotid artery under general anaesthetic (Sagatal; RMB Animal Health Limited, Dagenham, Essex). Arterial catheters were filled with sterile heparin-saline $(9 \mathrm{~g} \mathrm{NaCl} / 1$; 1000 units heparin $/ \mathrm{ml}$ ) containing $1 \mathrm{mg} / \mathrm{ml}$ benzylpenicillin (Crystapen; Glaxo Laboratories Limited, Greenford, Middx.) and flushed daily. On the day before estimates of hindlimb metabolism, PVC catheters (clear PVC tubing BSS 32, $1.00 \mathrm{~mm}$ i.d., $1.60 \mathrm{~mm}$ o.d.; Portex Limited, Hythe, Kent) were inserted into the jugular and deep femoral veins under local anaesthesia (Xylocaine without adrenalin; Astra Pharmaceuticals Limited, Home Park Estate, Kings Langley, Herts.). Femoral vein catheters were inserted via the caudal branch of the lateral saphenous vein so that the catheter tip lay in the deep femoral vein (Domanski et al. 1974; Oddy \& Lindsay, 1986; Teleni \& Annison, 1986). The length of femoral vein catheter inserted from a point level with the calcanei tuber was equal to the distance between the calcanei tuber and the trochanter major with the lamb standing normally. Extensive postmortem studies (twenty-six limbs) from this laboratory after using this method of placement have shown all catheter tips were located in the deep femoral vein. The jugular and femoral vein catheters were filled with sterile heparin-saline $(1000$ units/ml) and left overnight.

\section{Experimental procedures}

At $4 \mathrm{~d}$ before measurements of hindlimb metabolism were made the daily intakes of lambs were adjusted to give a range of feed intakes from well-fed to undernourished (see Table 2). On day 4 of dietary manipulation tyrosine metabolism across the hindlimb tissues was measured in all lambs. Each lamb was infused via the jugular vein catheter with L-[side 
chain $\left.2,3-{ }^{3} \mathrm{H}\right]$ tyrosine (Amersham International plc, Aylesbury, Bucks.) in sterile saline at a constant rate of $2 \mu \mathrm{Ci} / \mathrm{min}(0.5 \mathrm{ml} / \mathrm{min})$ for $6 \mathrm{~h}$, using a peristaltic pump (Gilson Minipulse 2; Anachem Limited, 20 Charles Street, Luton, Beds.). The infusion was started at 10.00 hours, $30 \mathrm{~min}$ after the morning feed, and continued until 16.00 hours. Blood samples $(10 \mathrm{ml})$ were withdrawn into heparinized syringes simultaneously from the carotid artery and deep femoral vein catheters at hourly intervals for the first $4 \mathrm{~h}$ of the infusion and at $30 \mathrm{~min}$ intervals during the final $2 \mathrm{~h}$ of the infusion. Blood samples were centrifuged at $4^{\circ}$ for $20 \mathrm{~min}$ at $2000 \mathrm{~g}$ and the plasma stored at $-20^{\circ}$ for subsequent analysis.

Hindlimb plasma flow rate was measured using the diffusion equilibrium technique of Pappenheimer \& Setchell (1972), as modified by Oddy et al. (1981) with tritiated water as the soluble marker. A solution of tritiated water was infused into the jugular vein at an exponentially decreasing rate for $60 \mathrm{~min}$. This was achieved by placing $250 \mu \mathrm{Ci}$ tritiated water in a $20 \mathrm{ml}$ vial, with a magnetic stirrer, and pumping tracer-free saline into the vial at $3 \mathrm{ml} / \mathrm{min}$. With the contents of the vial continually mixing, the outflow was infused into the jugular vein. The measurement of plasma flow rate was made between 15.00 and 16.00 hours, during the final hour of $\left[{ }^{3} \mathrm{H}\right]$ tyrosine infusion. Twenty sets of blood samples $(1 \mathrm{ml})$ were taken simultaneously from the carotid artery and deep femoral vein catheters into heparinized syringes during the infusion period and plasma prepared and stored at $-20^{\circ}$ for subsequent analysis. Animals had free access to feed and water throughout the experimental procedure.

After the $6 \mathrm{~h}$ blood samples had been taken the animals were anaesthetized with Sagatal, the infusion stopped and samples (approximately $15 \mathrm{~g}$ ) of the hindlimb muscles biceps femoris, vastus lateralis, gracilis and semimembranosus were rapidly removed from preshaven areas of the hindlimb, freeze-clamped in liquid $\mathrm{N}_{2}$ and stored at $-20^{\circ}$. Muscle samples were removed within 2 min of the initial anaesthetic dose and animals were then killed with a lethal amount of pentobarbitone (Euthatal; RMB Animal Health Limited). These four muscles were chosen since hindlimb blood drainage and catheter placement studies from this laboratory and by Teleni \& Annison (1986) have shown that blood from the muscles biceps femoris, semimembranosus and gracilis all contributed directly to blood draining into the deep femoral vein, whereas blood from the muscle vastus lateralis does not drain into the deep femoral vein.

\section{Analytical procedures}

The concentration and specific radioactivity (SRA) of tyrosine in plasma and muscle tissue were measured using HPLC with electrochemical detection, based on the method of Holman \& Snape (1983). Plasma was chosen since there was no significant difference between the mean arterio-venous difference of tyrosine across the hindlimb of lambs between blood and plasma (blood 3.22 (SEM 0.73), plasma 2.80 (SEM 0.57 ) nmol $/ \mathrm{ml} ; P=$ $0.370, n$ 16). Analysis was performed using a Constametric III metering pump (LDC/Milton Roy, Milton Roy House, Stone Business Park, Stone, Staffs.), a Rheodyne 7010 injection valve fitted with a 7025 loop filler port and $100 \mu \mathrm{l}$ sample loop, a $50 \mathrm{~mm} \times 4.6 \mathrm{~mm}$ internal diameter precolumn dry-packed with Whatmann Co:Pell ODS (Hichrom Limited, 6 Chiltern Enterprise Centre, Theale, Berks.) and a $250 \mathrm{~mm} \times 4.6 \mathrm{~mm}$ internal diameter, $5 \mu \mathrm{m}$ Hypersil ODS analytical column (Excel range; Hichrom Limited). The electrochemical detector was composed of an LC-2A electrochemical controller and a TL-8A thin-layer transducer (Anachem Limited). The electrochemical detector was maintained at an oxidizing potential of $+1 \cdot 0 \mathrm{~V}$. The mobile phase consisted of $0 \cdot 1 \mathrm{M}$-citric acid, 0.05 M-sodium citrate, $250 \mathrm{mg}$ EDTA/1 and $500 \mathrm{mg}$ octyl sodium sulphate/ (Kodak Laboratory \& Research Products, Acornfield Road, Knowsley Industrial Park North, Liverpool) ( $\mathrm{pH} 4.5)$ containing methanol $(50 \mathrm{ml} / \mathrm{l})$, which was filtered $(0.45 \mu \mathrm{m}$ pore size, 
HA type filter; Millipore, Watford, Herts.) and vacuum degassed for $10 \mathrm{~min}$ before use and pumped at $1 \mathrm{ml} / \mathrm{min}$, producing a back pressure of 2000-2300 psi.

For analysis of tyrosine concentration and SRA, $0.4 \mathrm{ml}$ plasma was mixed with $16 \mu 1$ 1.3 mm-3-amino-L-tyrosine (internal standard; Sigma Chemical Company Limited, Poole, Dorset) and centrifuged through a 30000 nominal molecular weight cutoff filter (UltrafreeMC units; Millipore) at $4^{\circ}$ for $2 \mathrm{~h}$ at $20000 \mathrm{~g}$. A $200 \mu \mathrm{l}$ portion of the filtrate was removed and acidified by the addition of $20 \mu 1$ perchloric acid $(330 \mathrm{~g} / 1)$. The acidified filtrate was mixed, centrifuged at $4^{\circ}$ for $10 \mathrm{~min}$ at $13000 \mathrm{~g}$ and $100 \mu \mathrm{l}$ taken for analysis using the HPLC system. The SRA of plasma tyrosine was measured by collecting the eluate from the electrochemical detector into a scintillation vial $50 \mathrm{~s}$ before and $1 \mathrm{~min}$ after the retention time for tyrosine. The radioactivity associated with the tyrosine peak was counted after the addition of $15 \mathrm{ml}$ scintillant (Ecoscint-A; National Diagnostics, Aylesbury, Bucks.). Samples analysed for tyrosine concentration and SRA using the conventional fluorimetric (Waalkes \& Udenfriend, 1957) and enzymic methods (Garlick \& Marshall, 1972) and the HPLC method showed there was no significant difference between the values for tyrosine concentration and SRA. The tritiated water content of plasma, for plasma flow rate determination, was measured as described by Pappenheimer \& Setchell (1972). The radioactivity associated with $0.1 \mathrm{ml}$ plasma was counted after the addition of $5 \mathrm{ml}$ of scintillant (Ecoscint-A; National Diagnostics).

Muscle samples for the determination of homogenate free and protein-bound tyrosine concentrations and SRA were prepared as described by Oddy \& Lindsay (1986). Radioactivity measurements were made in a Packard Tri-carb 2250CA liquid scintillant analyser (Packard Instruments, Brook House, Pangbourne, Berks.). Radioactivity values were corrected for quenching by the external-standard channels-ratio technique using appropriate quench curves and the efficiency of counting was between 40 and $50 \%$ for tritium.

\section{Calculations}

Hindlimb tyrosine exchange

$$
\begin{gathered}
\text { Arterio-venous difference }(\mathrm{nmol} / \mathrm{ml})=\mathrm{Ca}-\mathrm{Cv}, \\
\text { net extraction }(\%)=\frac{(\mathrm{Ca}-\mathrm{Cv})}{\mathrm{Ca}} \times 100, \\
\text { net exchange rate }(\mathrm{nmol} / \mathrm{min} \text { per } \mathrm{g})=(\mathrm{Ca}-\mathrm{Cv}) \times \mathrm{PF}, \\
\text { gross extraction }(\%)=\frac{(\mathrm{Ca} \times \mathrm{Sa}-\mathrm{Cv} \times \mathrm{Sv})}{\mathrm{Ca} \times \mathrm{Sa}} \times 100, \\
\text { gross uptake rate }(\mathrm{nmol} / \mathrm{min} \text { per } \mathrm{g})=\frac{(\mathrm{Ca} \times \mathrm{Sa}-\mathrm{Cv} \times \mathrm{Sv})}{\mathrm{Sa}} \times \mathrm{PF}, \\
\text { gross release rate }(\mathrm{nmol} / \mathrm{min} \text { per } \mathrm{g})=(5)-(3),
\end{gathered}
$$

where $\mathrm{Ca}$ and $\mathrm{Cv}$ represent the concentration of tyrosine in arterial and femoral vein plasma $(\mathrm{nmol} / \mathrm{ml}), \mathrm{Sa}$ and $\mathrm{Sv}$ represent the SRA of tyrosine in arterial and femoral vein plasma (disintegrations/min (dpm) per nmol) during the final $2 \mathrm{~h}$ sampling period and $\mathrm{PF}$ represents the hindlimb plasma flow rate $(\mathrm{ml} / \mathrm{min}$ per $\mathrm{g})$.

\section{Hindlimb protein turnover}

Hindlimb protein gain $\left(k_{g a v} ; \% / \mathrm{d}\right)=\frac{\text { net exchange rate } \times 144}{\text { tyrosine content of muscle }}$, 
Table 1. Regression analysis of changes in the values of arterial $(A)$ and femoral vein (V) tyrosine concentration and specific radioactivity during the final $2 \mathrm{~h}$ sampling period in nine lambs receiving different dry matter intakes

(Mean values with their standard errors)

\begin{tabular}{|c|c|c|c|c|c|c|}
\hline Measurement & Sample & Mean & SEM & $\begin{array}{l}\text { Slope of } \\
\text { regression line } \\
\text { (change } / 0.5 \mathrm{~h} \text { ) }\end{array}$ & $\begin{array}{l}\text { Change during } \\
\text { sampling } \\
\text { period }(\%)\end{array}$ & $\begin{array}{c}\text { Statistical } \\
\text { significance }\end{array}$ \\
\hline \multirow{2}{*}{$\begin{array}{l}\text { Tyrosine concentration } \\
(\mathrm{nmol} / \mathrm{ml})\end{array}$} & A & $46 \cdot 01$ & 6.42 & $0 \cdot 10$ & 2.99 & NS \\
\hline & $\mathrm{V}$ & 46.68 & $5 \cdot 43$ & $0 \cdot 14$ & $3 \cdot 28$ & NS \\
\hline \multirow{2}{*}{$\begin{array}{l}\text { Tyrosine SRA } \\
\text { (dpm/nmol) }\end{array}$} & A & $133 \cdot 5$ & $11 \cdot 78$ & $-0 \cdot 06$ & -0.78 & NS \\
\hline & V & 96.99 & $4 \cdot 88$ & -0.07 & -0.41 & NS \\
\hline
\end{tabular}

NS, not significantly different from zero $(P>0.1)$; dpm, disintegrations $/ \mathrm{min}$.

$$
\text { hindlimb protein synthesis }\left(k_{\text {sav }} ; \% / \mathrm{d}\right)=\frac{\text { gross uptake rate } \times 144}{\text { tyrosine content of muscle }}
$$

$$
\text { hindlimb protein degradation }\left(k_{d a v} ; \% / \mathrm{d}\right)=k_{s a v}-k_{g a v} \text {, }
$$

where 144 is the factor used to convert exchange rates from 'per min' to 'per d'. As the tyrosine content of the hindlimb tissues contributing to the blood sampled in the deep femoral vein cannot be determined directly, the tyrosine content of muscle was used. The mean tyrosine content of sheep muscle was 32.811 (SEM $0.882 ; n 9$ ) $\mathrm{mmol} / \mathrm{kg}$ wet weight.

Muscle protein synthesis. The rate of muscle protein synthesis was calculated using the equation of Garlick et al. (1973) for tissues with a slow turnover.

$$
\frac{S_{b}}{S_{i}}=\frac{R}{(R-1)} \times \frac{\left(1-e^{-k s t}\right)}{\left(1-e^{-R k k t}\right)}-\frac{1}{(R-1)},
$$

where $S_{b}$ and $S_{i}$ represent the SRA of tyrosine in the protein-bound and intracellular free fractions of muscle (dpm/nmol), $t$ is the duration of the infusion (d), $R$ is the concentration ratio, protein-bound tyrosine:intracellular free tyrosine, and showed no significant differences between the four individual muscles sampled, the mean value being 636 (SEM 58; $n 9)$ and $k_{s}$ is the fractional synthetic rate $(\% / \mathrm{d})$.

\section{Statistics}

To assess that steady-state conditions existed, regression analyses were carried out to calculate the percentage change with time in plasma tyrosine concentration and SRA over the final $2 \mathrm{~h}$ sampling period (Baird et al. 1983). The statistical significance of the change from zero was assessed using Student's $t$ test. Regression analyses were employed to (a) establish relationships between DM intake and tyrosine metabolism and protein turnover and (b) demonstrate that the slopes and intercepts of the regression lines were not significantly different. The statistical significance of differences between the mean estimates of protein synthesis calculated using the two different techniques was assessed using Student's paired $t$ test. 


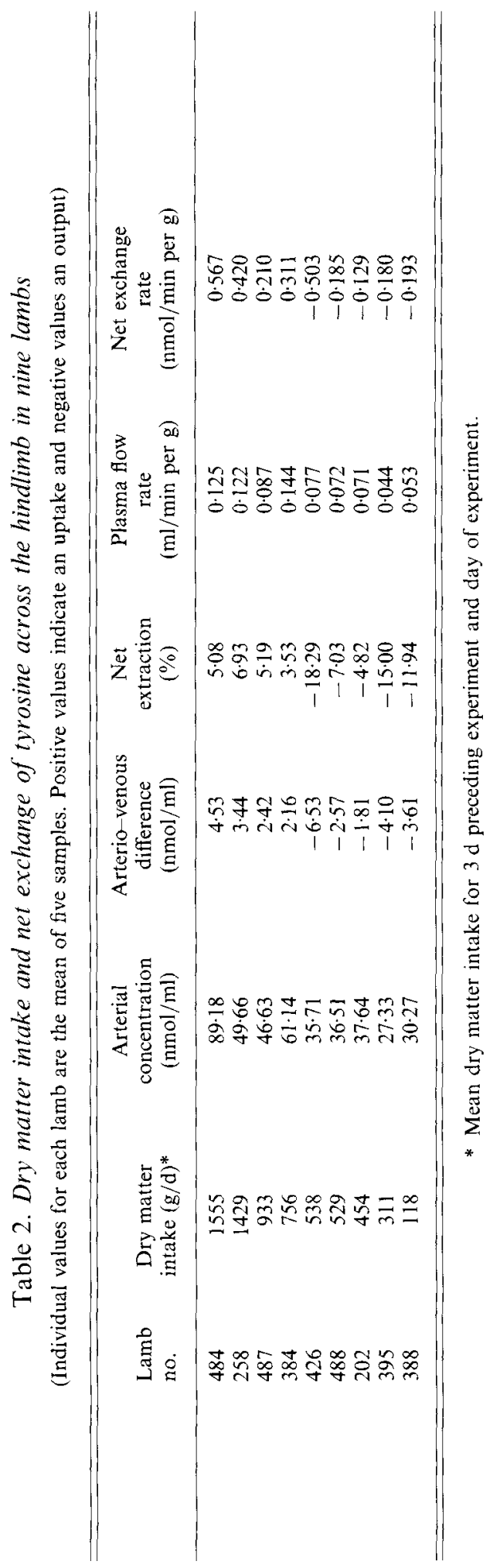


Table 3. Gross exchange of tyrosine across the hindlimb in nine lambs receiving different dry matter intakes*

(Individual values for each lamb are the mean of five samples)

\begin{tabular}{|c|c|c|c|c|}
\hline $\begin{array}{l}\text { Lamb } \\
\text { no. }\end{array}$ & $\begin{array}{c}\text { Arterial } \\
\text { SRA } \\
\text { (dpm/nmol) }\end{array}$ & $\begin{array}{l}\text { Gross } \\
\text { extraction } \\
(\%)\end{array}$ & $\begin{array}{l}\text { Gross uptake } \\
\text { rate } \\
(\mathrm{nmol} / \mathrm{min} \text { per } \mathrm{g})\end{array}$ & $\begin{array}{c}\text { Gross release } \\
\text { rate } \\
\text { (nmol/min per } \mathrm{g} \text { ) }\end{array}$ \\
\hline 484 & $73 \cdot 11$ & 11.45 & $1 \cdot 277$ & 0.710 \\
\hline 258 & $88 \cdot 51$ & $17 \cdot 66$ & 1.070 & 0.650 \\
\hline 487 & $126 \cdot 8$ & $22 \cdot 66$ & 0.919 & 0.709 \\
\hline 384 & 116.8 & 14.68 & $1 \cdot 293$ & 0.982 \\
\hline 426 & 146.6 & $24 \cdot 66$ & 0.684 & $1 \cdot 187$ \\
\hline 488 & $146 \cdot 2$ & $27 \cdot 47$ & 0.722 & 0.907 \\
\hline 202 & $162 \cdot 4$ & $29 \cdot 62$ & 0.792 & 0.921 \\
\hline 395 & $177 \cdot 5$ & $28 \cdot 86$ & 0.347 & 0.527 \\
\hline 388 & $163-3$ & $25 \cdot 64$ & 0.411 & 0.604 \\
\hline
\end{tabular}

dpm, Disintegrations/min

* For details of intakes, see Table 2.

\section{RESULTS}

\section{Hindlimb tyrosine exchange and protein turnover}

The calculations for hindlimb tyrosine metabolism assume that steady-state conditions existed across the hindlimb during the sampling period. Regression analysis indicated that average changes during the final $2 \mathrm{~h}$ of sampling in the magnitude of tyrosine concentration and SRA in arterial and venous plasma were less than $4 \%$ (not significantly different from zero) and showed no consistent changes with time (Table 1). Therefore, steady-state conditions had been achieved across the hindlimb during the final $2 \mathrm{~h}$ sampling period (Baird et al. 1983).

The mean live weight of all nine lambs on the day of experiment was 36.5 (SEM 0.7 , range $31.5-38.0) \mathrm{kg}$. Decreasing feed intake caused a decrease in arterial plasma tyrosine concentration and hindlimb plasma flow rate, and converted the net uptake of tyrosine to a net output at or below feed intake to maintain zero energy balance (Table 2). There were significant relationships between DM intake $(x)$ and the values for arterial tyrosine concentration $\left(r^{2} 0.684, P=0.006\right)$, net arterio-venous difference $\left(r^{2} 0.720, P=0.004\right)$, net extraction $\left(r^{2} 0.645, P=0.009\right)$, plasma flow rate $\left(r^{2} 0.612, P=0.013\right)$ and net exchange rate $\left(r^{2} 0.718, P=0.004\right)$. There was a significant relationship between arterial tyrosine concentration $(x)$ and the arterio-venous difference of tyrosine across the hindlimb $\left(y ; r^{2}\right.$ $0.647, P=0.009$ ).

Despite the net output of tyrosine from the hindlimb of lambs fed below maintenance energy intake, the use of radiolabelled tyrosine demonstrated that there was a simultaneous gross uptake (removal of arterial tyrosine across the hindlimb) and gross release (release of unlabelled tyrosine from the hindlimb tissues into plasma) across the hindlimb in all lambs irrespective of nutritional state (Table 3). The gross extraction of radiolabelled tyrosine across the hindlimb $(y)$ was inversely related to DM intake $\left(r^{2}-0.660, P=0.008\right)$ and arterial tyrosine concentration $\left(r^{2}-0.828, P<0.001\right)$. The gross uptake rate of tyrosine was lower during submaintenance feeding, but tyrosine gross release rate was unchanged by feed level. There was a significant relationship between the gross uptake rate $(y)$ and DM intake $\left(r^{2} 0.667, P=0.007\right)$. The fractional rates of hindlimb protein turnover, estimated from measurements of tyrosine exchange across the hindlimb, are given in Table 4 and demonstrate that hindlimb protein synthesis and gain, but not degradation, increased with the rise in feed intake. 
Table 4. Muscle homogenate free tyrosine concentration and specific radioactivity (SRA), the fractional rates of muscle protein synthesis and hindlimb protein turnover (estimated from measurements of tyrosine exchange across the hindlimb) in nine lambs receiving different dry matter intakes*

(Individual values. Positive values indicate a net gain of protein and negative values a net loss)

\begin{tabular}{|c|c|c|c|c|c|c|c|}
\hline \multirow[b]{2}{*}{$\begin{array}{l}\text { Lamb } \\
\text { no. }\end{array}$} & \multicolumn{2}{|c|}{ Homogenate free tyrosine } & \multicolumn{2}{|c|}{$\begin{array}{l}\text { Fractional rate muscle } \\
\text { protein synthesis }(\% / d)\end{array}$} & \multicolumn{3}{|c|}{$\begin{array}{l}\text { Fractional rates of hindlimb } \\
\text { protein turnover }(\% / \mathrm{d})\end{array}$} \\
\hline & $\begin{array}{l}\text { Concentration }{ }^{\dagger} \\
(\mathrm{nmol} / \mathrm{ml})\end{array}$ & $\begin{array}{c}\text { SRA } \\
(\mathrm{dpm} / \mathrm{nmol})\end{array}$ & $k_{s p}$ & $k_{s h}$ & $k_{g a v}$ & $k_{s a v}$ & $k_{d a t}$ \\
\hline 484 & $136 \cdot 24$ & $41 \cdot 71$ & $3 \cdot 48$ & 5.29 & 2.49 & $5 \cdot 60$ & $3 \cdot 11$ \\
\hline 258 & 71.68 & $59 \cdot 73$ & $3 \cdot 62$ & $5 \cdot 13$ & $1 \cdot 84$ & $4 \cdot 70$ & $2 \cdot 85$ \\
\hline 487 & $81 \cdot 18$ & $69 \cdot 56$ & $2 \cdot 36$ & 3.65 & 0.92 & $4 \cdot 03$ & $3 \cdot 11$ \\
\hline 384 & $92 \cdot 14$ & $75 \cdot 43$ & 2.73 & 3.79 & $1 \cdot 37$ & $5 \cdot 68$ & $4 \cdot 31$ \\
\hline 426 & $71 \cdot 70$ & $64 \cdot 58$ & 1.69 & 3.06 & $-2 \cdot 21$ & $3 \cdot 00$ & $5 \cdot 21$ \\
\hline 488 & $62 \cdot 50$ & $79 \cdot 11$ & 1.69 & $2 \cdot 68$ & -0.81 & $3 \cdot 17$ & 3.98 \\
\hline 202 & $85 \cdot 86$ & $75 \cdot 56$ & 1.64 & $2 \cdot 62$ & -0.57 & $3 \cdot 48$ & $4 \cdot 04$ \\
\hline 395 & $54 \cdot 75$ & $87 \cdot 26$ & 1.44 & $2 \cdot 43$ & -0.79 & $1 \cdot 52$ & $2 \cdot 31$ \\
\hline 388 & $59 \cdot 41$ & $80 \cdot 54$ & 1.00 & 1.46 & -0.85 & 1.80 & 2.65 \\
\hline
\end{tabular}

$k_{s y}$, Calculated using the arterial plasma free tyrosine SRA; $k_{s h}$, calculated using the homogenate free tyrosine SRA; $k_{g a v}$, hindlimb protein gain; $k_{s a v}$, hindlimb protein synthesis; $k_{d a v}$ hindlimb protein degradation.

* For details of intakes, see Table 2 .

$\uparrow$ Calculated using water content of muscle tissue.

\section{Muscle protein synthesis}

The average fractional rates of muscle protein synthesis $\left(k_{s h}\right)$ measured over the range of DM intakes were not significantly different between the four muscles examined from each lamb. Mean values for biceps femoris, vastus lateralis, gracilis and semimembranosus were 3.45 (SEM 0.54), 3.32 (SEM 0.38), 3.41 (SEM 0.42), 3.21 (SEM 0.46) \%/d respectively. Therefore, the values for the four individual muscles were pooled to derive a mean rate of muscle protein synthesis in each lamb.

Water and perchloric acid-precipitable protein content of muscle tissue were unaffected by reduced feed intake, the mean values for all nine lambs being $70 \cdot 11$ (SEM 0.66) \% and 18.35 (SEM 0.33) \% respectively. The SRA of homogenate free tyrosine $\left(S_{h}\right)$ was lower than that of plasma $\left(S_{a}\right)$ (Tables 3 and 4 ), the average value for $S_{h}: S_{a}$ being 0.545 (SEM 0.026 ).

The fractional rates of muscle protein synthesis were calculated using both the arterial plasma free tyrosine SRA $\left(k_{s p}\right)$ and the homogenate free tyrosine SRA $\left(k_{s h}\right)$; these values are given in Table 4 . The two estimates of muscle protein synthesis, $k_{s p}$ and $k_{s h}$, both declined in response to decreasing feed intake. The homogenate free SRA contains extracellular fluid but calculation of intracellular free SRA based on $0.14 \mathrm{ml}$ extracellular fluid/g muscle tissue in dogs (Horber et al. 1989) showed that the mean value for all nine lambs for muscle protein synthesis calculated using the intracellular free SRA $\left(k_{s i}\right)$ was only $7.5 \%$ larger than that for $k_{s h}\left(k_{s i}, 3.60(\right.$ SEM 0.44$\left.) \% / d\right)$. Since no values are available for the contribution of extracellular fluid to muscle weight in sheep under different nutritional situations, only values for muscle protein synthesis calculated using the homogenate free tyrosine SRA are reported. 


\section{DISCUSSION}

\section{Protein turnover measurement}

The major problem involved in using tracer amino acid kinetics to measure tissue protein synthesis arises from a failure to measure directly the SRA of the tracer amino acid in aminoacyl-tRNA, the true precursor pool of protein synthesis. When using a continuous infusion of tracer amino acid, tissue protein synthesis can be calculated from the SRA of the plasma free pool, the SRA of the intracellular free pool (usually estimated from the SRA in the homogenate free pool) or the SRA of the plasma transamination product ( $\alpha$-ketoisocaproate) pool, during tracer leucine infusions (Matthews et al. 1982). In muscle tissue, throughout the range of dry matter intakes, the homogenate free tyrosine SRA was approximately $50 \%$ of the plasma free tyrosine SRA (Tables 3 and 4), with the result that muscle protein synthetic rates based on arterial plasma free tyrosine SRA $\left(k_{s p}\right)$ were $50 \%$ lower than those based on muscle homogenate free tyrosine SRA $\left(k_{s h}\right)$ (Table 4). This difference between intracellular and plasma SRA is due to dilution of the intracellular free pool by amino acids released during protein degradation (see Waterlow et al. 1978). Airhart et al. (1982) have provided evidence that the SRA of aminoacyl-tRNA in muscle cells is approximately half-way between the extracellular and intracellular free SRA, due to preferential acylation of amino acids transported into cells, by plasma membrane bound aminoacyl-tRNA synthetases (Airhart et al. 1974).

Due to this uncertainty regarding precursor pool SRA, protein synthetic rates are generally given as a range of values, since $k_{s p}$ will be minimum estimates while values for $k_{s h}$ will give upper estimates. The values for $k_{s p}$ and $k_{s h}$ obtained in the present study are comparable with those reported in previous studies measuring muscle protein synthesis in similar animals (Davis et al. 1981; Oddy \& Lindsay, 1986; Bohorov et al. 1987; Lobley et al. 1990; Harris \& Lobley, 1991).

The hindlimb method measures the arterio-venous differences in tyrosine concentration and SRA across the hindlimb during a constant infusion of isotopically-labelled tyrosine. Protein gain is estimated from the net mass transfer of tyrosine across the hindlimb (net exchange rate) and protein synthesis is estimated from the rate of transfer of isotopically-labelled tyrosine from the arterial plasma pool into the intracellular hindlimb tissue pool (gross extraction and gross uptake rate). Relating this isotope transfer to the actual mass of tyrosine utilized across the hindlimb requires knowledge of both the precursor pool (in this case the arterial plasma free tyrosine pool) and the amount of tyrosine of lower SRA, originating from the intracellular pool and contributing to the venous drainage (estimated from the dilution of tyrosine SRA across the hindlimb). The gross mass transfer of tyrosine is assumed to be equal to the rate of protein synthesis, given that tyrosine is not further metabolized by these tissues. The calculation of protein synthesis using the hindlimb method, therefore, assumes that the SRA of tyrosine in the arterial plasma free pool defines the precursor pool of tyrosine used for protein synthesis. In theory, hindlimb protein degradation is calculated from the dilution of tyrosine SRA between the artery and the deep femoral vein, although in practice it is simpler to calculate protein degradation from the difference between protein synthesis and gain. Hindlimb protein synthesis and degradation will be underestimated by the amount of unlabelled tyrosine released into the intracellular free pool from protein degradation and reused for protein synthesis and, therefore, not released into the venous drainage. The values for $k_{\text {sav }}$ and $k_{d a v}$ obtained in the present study are also comparable with those reported in previous studies measuring hindlimb protein turnover in similar animals using isotopically-labelled tyrosine (Vincent, 1984), leucine (Oddy \& Lindsay, 1986) and phenylalanine (Garlick \& Lobley, 1987). 
The estimates of hindlimb protein synthesis should theoretically be similar to those for muscle protein synthesis calculated using the plasma SRA, since both calculations assume that the SRA of tyrosine in the arterial plasma free pool is the same as the SRA of tyrosine in the direct precursor pool of protein synthesis. Therefore, it would be expected that the values for $k_{s a v}$ should be approximately equal to $k_{s p}$ and half $k_{s n}$. However, the mean values for all nine lambs showed that $k_{s a v}(3.66$ (SEM 0.50$) \% /$ d) was significantly $(P<0.001)$ higher $(68 \%)$ than $k_{s p}(2.18$ (SEM 0.31$) \% / d$ ) but was similar to $k_{s h}(3.35$ (SEM 0.42$) \% / d$ ) (Table 4). Previous studies which have measured hindlimb protein synthesis and muscle protein synthesis simultaneously in sheep, have similarly reported $k_{\text {sav }}$ to be $41 \%$ higher than $k_{s p}$ (Oddy et al. 1988) and no significant difference between $k_{s a v}$ and $k_{s h}$ (Oddy \& Lindsay, 1986). Halliday et al. (1988), summarizing findings from previous studies (Cheng et al. 1987, 1988; Pacy et al. 1988), have also reported values for protein synthesis in the quadriceps muscles which are similar to those determined separately across the human forearm using an arterio-venous difference method.

The higher values for $k_{s a v}$ than theoretically predicted from the value for $k_{s p}$ can be explained by one or more of the following: (a) metabolism of the tracer amino acid by tissues of the hindlimb, (b) overestimation of hindlimb plasma flow rate and (c) heterogeneity of hindlimb tissues results in the contribution of tissues with higher protein synthetic rates than muscle.

The method assumes that the only metabolic fate of the tracer amino acid in limb tissues is synthesis into protein. Goldberg et al. (1980) have stated that this assumption is correct for tyrosine and supporting evidence comes from the distribution of tyrosine transaminase ( $E C$ 2.6.1.5), the rate-limiting enzyme in the oxidative catabolism of tyrosine (e.g. Coufalik \& Monder, 1978), which is absent in rat muscle tissue and exists entirely in liver (Granner \& Hargrove, 1983). Mitochondrial aspartate transaminase (EC 2.6.1.1) is able to transaminate tyrosine, but this enzyme is unlikely to utilize significant quantities of tyrosine at physiological tyrosine concentrations $(60 \mu \mathrm{M})$ and in the presence of aspartate (Ohisalo et al. 1982). These findings are supported by results from studies in vivo which have demonstrated no significant release of tritiated water and therefore transamination of tyrosine across hindlimb tissues in lambs (Vincent, 1984; Crompton, 1990) and no significant oxidation of tyrosine across a skin preparation in sheep (Harris et al. 1989a). Furthermore, the higher values for $k_{s a v}$ compared with $k_{s p}$ have been demonstrated using other isotopically-labelled amino acids (see p. 353) and are, therefore, not specific to the use of tyrosine.

Higher estimates of $k_{s a v}$ compared with $k_{i p}$ may be the result of overestimating hindlimb plasma flow rate; however, this is unlikely since the diffusion equilibrium technique has been validated using microspheres (Oddy et al. 1981) and downstream dye dilution techniques within the deep femoral vein (Teleni \& Annison, 1986; Crompton, 1990). Values in the present study are also similar to previous reports (e.g. Oddy \& Lindsay, 1986; Teleni et al. 1986). Hindlimb blood flow rate is stimulated by direct exercise (Bird et al. 1981; Pethick et al. 1987) and one of the major sources of variation in blood flow across the hindlimb is the animal's level of activity. To minimize the effects of postural changes on blood flow and the proportion of sampled blood from different tissues, all lambs used in the present study were accustomed to the experimental protocol before measurements were taken and trained to stand still during blood sampling periods. The measurement of hindlimb plasma flow rate relative to the weight of tissue being drained allows the estimation of fractional rates of protein metabolism to be calculated based on the average tyrosine content of muscle protein. This avoids the necessity of assuming a constant relationship between blood flow and muscle drainage in order to calculate fractional synthetic rates, as used in other studies of limb protein metabolism (Barrett et al. 1987; Cheng et al. 1987; Gelfand \& Barrett, 1987; Thompson et al., 1989). 
The major difficulty encountered when using hindlimb preparations to assess protein turnover is the heterogeneity of the tissue bed being studied. Using the hindlimb preparation it has been shown that careful placement of the venous sampling catheter tip in the deep femoral vein should ensure that muscle tissue makes by far the largest contribution (approximately $90 \%$ ) to the blood sampled, with only a 10\% contribution from non-muscular sources (i.e. subcutaneous and intramuscular adipose tissue, skin, cartilage and bone; Domanski et al. 1974; Oddy et al. 1981; Teleni \& Annison, 1986; L. A. Crompton and M. A. Lomax, unpublished results). However, in adult sheep the relative contributions of muscle, bone, skin and adipose tissue to the blood sampled in the deep femoral vein have been estimated at 61, 22, 12 and 5\% respectively (Oddy et al. 1984).

The protein metabolic activity of skin and bone is considerably higher than that for muscle and drainage from these tissues would increase hindlimb protein synthesis above that for muscle. Values for protein synthetic rates $(\% / d)$ in ruminant lambs are: skin 11 , muscle 2.9 (Harris \& Lobley, 1991), skin 20.5, muscle 3.22 (Abdul-Razzaq \& Bickerstaffe, 1989), skin 17.0, muscle $2 \cdot 35$ (Chambers \& Bickerstaffe, 1982); in piglets, bone 26, muscle 13 (Seve et al. 1986); and in the growing rat, skin 63.6, bone 90.4, muscle 16.9 (Preedy et al. 1983). Assuming a minimum contribution from non-muscular tissues of $10 \%$, protein synthetic rates of $3 \% / \mathrm{d}$ in muscle and $15 \% / \mathrm{d}$ in skin and bone would result in a value for hindlimb protein synthesis of $4.2 \% / \mathrm{d}$. Thus, together non-muscular tissues could contribute a minimum of approximately $36 \%$ to the value for $k_{s a t}$.

Therefore, the most probable explanation for the $68 \%$ overestimation of $k_{s a v}$ when compared on a theoretical basis with $k_{s p}$ is that $k_{s a v}$ measures protein synthesis in the mixed tissues of the hindlimb and should not be equated with muscle protein synthesis as suggested by others (Oddy \& Lindsay, 1986; Barrett et al. 1987; Gelfand \& Barrett, 1987), but may be more representative of carcass protein synthesis since it has been reported that carcass protein synthesis was approximately $60 \%$ higher than muscle protein synthesis in cattle (Lobley et al. 1980). Similarly, the values for $k_{g a v}$ and $k_{d a v}$ will represent protein gain and degradation across hindlimb tissues.

\section{Effect of feed intake on protein turnover}

Other workers have demonstrated that both hindlimb and muscle protein synthesis rates increase with increasing feed intake in ruminants (Bryant \& Smith, 1982; Garlick \& Lobley, 1987; Harris et al. 1989 b; Harris \& Lobley, 1991). In the present study the estimates of hindlimb and muscle protein synthesis $(y)$ were significantly related to DM intake $(x)$ $\left(k_{s a l}, r^{2} 0.667, P=0.007 ; k_{s h}, r^{2} 0.968, P<0.001\right)$ and there was no significant difference between the slopes $(P=0.532)$ and intercepts $(P=0.945)$ of the two regression lines. Although $k_{s a v}$ and $k_{s h}$ are calculated using the SRA of tyrosine in two different pools, direct comparison of the two sets of values showed there was no significant difference $(P=0 \cdot 260)$ between the mean values for $k_{s a v}$ and $k_{s h}$ when measured simultaneously. These results demonstrate that throughout the range of feed intakes both the absolute values and the response to nutrition were not significantly different between $k_{s a v}$ and $k_{s h}$, and suggest that the relationships between protein synthesis and different hindlimb tissues and the SRA in plasma and intracellular pools remains constant with respect to feed intake.

Hindlimb protein degradation did not alter appreciably with increasing feed intake despite a net protein loss $\left(k_{g a v}\right)$ across the hindlimb in lambs fed at maintenance or below and net protein gain in well-fed lambs (Table 4). Hindlimb protein gain $(y)$ was significantly related to DM intake $\left(x ; r^{2} 0 \cdot 718, P=0.004\right)$. This agrees with previous studies showing that changes in muscle protein mass in relation to feed intake are largely due to changes in muscle fractional synthetic rate (Table 4).

It is concluded that the arterio-venous difference method is capable of measuring the impact of nutrition on protein turnover in hindlimb tissues. Although the responses to 
nutrition in hindlimb and muscle tissues were similar it is likely that non-muscular tissues make an appreciable contribution to hindlimb protein turnover. The major advantage of the hindlimb arterio venous difference method is that it enables the rate of hindlimb tissue protein gain, synthesis and degradation to be determined simultaneously in vivo, and it can, therefore, be used serially for large animal and clinical studies.

The financial support of the Agricultural and Food Research Council is gratefully acknowledged.

\section{REFERENCES}

Abdul-Razzaq, H. A. \& Bickerstaffe, R. (1989). The influence of rumen volatile fatty acids on protein metabolism in growing lambs. British Journal of Nutrition 62, 297-310.

Airhart, J., Arnold, J. A., Stirewalt, W. S. \& Low, R. B. (1982). Insulin stimulation of protein synthesis in cultured skeletal and cardiac muscle cells. American Journal of Physiology 243, C81-C86.

Airhart, J., Vidrich, A. \& Khairallah, E. A. (1974). Compartmentation of free amino acids for protein synthesis in rat liver. Biochemical Journal 140, 539--548.

Baird, G. D., Van Der Walt, J. G. \& Bergman, E. N. (1983). Whole-body metabolism of glucose and lactate in productive sheep and cows. British Journal of Nutrition 50, 249-265.

Barrett, E. J. \& Gelfand, R. A. (1989). The in vivo study of cardiac and skeletal muscle protein turnover. Diabetes Metabolism Reviews 5, 133-148.

Barrett, E. J., Revkin, J. H., Young, L. H., Zaret, B. L., Jacob, R. \& Gelfand, R. A. (1987). An isotopic method for measurement of muscle protein synthesis and degradation in vivo. Biochemical Journal 245, 223-228.

Bird, A. R., Chandler, K. D. \& Bell, A. W. (1981). Effects of exercise and plane of nutrition on nutrient utilisation by the hind-limb of sheep. Australian Journal of Biological Sciences 34, 541-550.

Bohorov, O., Buttery, P. J., Correia, J. H. R. D. \& Soar, J. B. (1987). The effect of the $\beta$-2-adrenergic agonist clenbuterol or implantation with oestradiol plus trenbolone acetate on protein metabolism in wether lambs. British Journal of Nutrition 57, 99-107.

Boisclair, Y., Bauman, D. E., Bell, A. W. \& Dunshea, F. R. (1988). Muscle protein synthesis and whole body N balance in fed and underfed steers. FASEB Journal 2, A848.

Bryant, D. T. W. \& Smith, R. W. (1982). Protein synthesis in muscle of mature sheep. Journal of Agricultural Science, Cambridge 98, 639-643.

Chambers, J. A. \& Bickerstaffe, R. (1982). Effect of rumen development on protein synthesis in lambs. Proceedings of the Nutrition Society of Australia 7, 148.

Cheng, K. N., Dworzak, F., Ford, G. C., Rennie, M. J. \& Halliday, D. (1985). Direct determination of leucine metabolism and protein breakdown in humans using $\mathrm{L}-\left[1-{ }^{13} \mathrm{C},{ }^{15} \mathrm{~N}\right]$-leucine and the forearm model. European Journal of Clinical Investigation 15, 349-354.

Cheng, K. N., Pacy, P. J., Dworzak, F., Ford, G. C. \& Halliday, D. (1987). Influence of fasting on leucine and muscle protein metabolism across the forearm determined using $\mathrm{L}-\left[1-{ }^{13} \mathrm{C},{ }^{15} \mathrm{~N}\right]$-leucine as the tracer. Clinical Science 73, 241-246.

Cheng, K. N., Pacy, P. J., Hicks, C., Ford, G. C., Merritt, H. \& Halliday, D. (1988). A non-invasive technique for determining muscle protein synthesis. Proceedings of the Nutrition Society 47, 54 A.

Coufalik, A. \& Monder, C. (1978). Perinatal development of the tyrosine oxidising system. Biology of the Neonate 34, 161-166.

Crompton, L. A. (1990). Acute nutritional signals in the control of hind-limb protein turnover in lambs in vivo. PhD Thesis, University of Reading.

Davis, S. R., Barry, T. N. \& Hughson, G. A. (1981). Protein synthesis in tissues of growing lambs. British Journal of Nutrition 46, $409-419$.

Domanski, A., Lindsay, D. B. \& Setchell, B. P. (1974). Blood flow and substrate uptake and oxidation in the hindlimb muscles of sheep. Journal of Physiology 242, 28P-29P.

Garlick, P. J. \& Lobley, G. E. (1987). Dietary intake and protein turnover. In Protein Metabolism and Nutrition. European Association of Animal Production, Publication no. 35, pp. 18-21. Rostock, Germany: Wilhelm-PieckUniversität.

Garlick, P. J., McNurlan, M. A. \& Preedy, V. R. (1980). A rapid and convenient technique for measuring the rate of protein synthesis in tissues by injection of $\left[{ }^{3} \mathrm{H}\right]$ phenylalanine. Biochemical Journal 192, 719-723.

Garlick, P. J. \& Marshall, I. (1972). A technique for measuring brain protein synthesis. Journal of Neurochemistry 19, 577-583.

Garlick, P. J., Millward, D. J. \& James, W. P. T. (1973). The diurnal response of muscle and liver protein synthesis in vivo in meal-fed rats. Biochemical Journal 136, 935-945.

Gelfand, R. A. \& Barrett, E. J. (1987). Effect of physiologic hyperinsulinemia on skeletal muscle protein synthesis and breakdown in man. Journal of Clinical Investigation 80, 1-6. 
Goldberg, A. L., Tischler, M., DeMartino, G. \& Griffin, G. (1980). Hormonal regulation of protein degradation and synthesis in skeletal muscle. Federation Proceedings 39, 31-36.

Granner, D. K. \& Hargrove, J. L. (1983). Regulation of the synthesis of tyrosine aminotransferase: the relationship to mRNA ${ }^{\text {TAT }}$. Molecular and Cellular Biochemistry 53/54, 113-128.

Halliday, D., Pacy, P. J., Cheng, K. N., Dworzak, F., Gibson, J. N. \& Rennie, M. J. (1988). Rate of protein synthesis in skeletal muscle of normal man and patients with muscular dystrophy: a reassessment. Clinical Science 74, 237-240.

Harris, C. I. \& Milne, G. (1977). The unreliability of urinary 3-methylhistidine excretion as a measure of muscle protein degradation in sheep. Proceedings of the Nutrition Society 35, $138 \mathrm{~A}$.

Harris, C. 1. \& Milne, G. (1980). The urinary excretion of $N$-methylhistidine in sheep: an invalid index of muscle protein breakdown. British Journal of Nutrition 44, 129-140.

Harris, P. M., Dellow, D. W. \& Sinclair, B. R. (1989a). Preliminary 'in vivo' measurements of protein and energy metabolism in the skin of sheep. Australian Journal of Agricultural Science 40, 879-888.

Harris, P. M., Garlick, P. J. \& Lobley, G. E. (1989b). Interactions between energy and protein metabolism in the whole body and hind-limb of sheep in response to intake. In Energy Metabolism of Farm Animals, European Association of Animal Production, Publication no. 43, pp. 167-170 [Y. van der Honing and W. H. Close, editors]. Wageningen, The Netherlands: Pudoc.

Harris, P. M. \& Lobley, G. E. (1991). Amino acid and energy metabolism in the peripheral tissues of ruminants. In Physiological Aspects of Digestion and Metabolism in Ruminants, pp. 201-230 [T. Tsuda, Y. Sasaki and R. Kawashima, editors]. London: Academic Press.

Holman, R. B. \& Snape, B. M. (1983). Determination of L-tyrosine in rat brain by reverse-phase liquid chromatography with electrochemical detection. Journal of Chromatography 262, 415-419.

Horber, F. F., Horber-Feyder, C. M., Krayer, S., Schwenk, W. F. \& Haymond, M. W. (1989). Plasma reciprocal pool specific activity predicts that of intracellular free leucine for protein synthesis. American Journal of Physiology 257, E385-E399.

Lobley, G. E., Connell, A., Milne, E., Buchan, V., Calder, A. G., Anderson, S. E. \& Vint, H. (1990). Muscle protein synthesis in response to testosterone administration in wether lambs. British Journal of Nutrition 64 , 691-704.

Lobley, G. E., Milne, V., Lovie, J. M., Reeds, P. J. \& Pennie, K. (1980). Whole body and tissue protein synthesis in cattle. British Journal of Nutrition 43, 491-502.

Matthews, D. E., Schwarz, H. P., Yang, R. D., Motil, K. J., Young, V. R, \& Bier, D. M. (1982). Relationship of plasma leucine and $\alpha$-ketoisocaproate during a $\mathrm{L}-\left[1-{ }^{13} \mathrm{C}\right]$ leucine infusion in man: a method for measuring human intracellular leucine tracer enrichment. Metabolism 31, 1105-1112.

Ministry of Agriculture, Fisheries and Food (1984). Energy Allowances and Feeding Systems for Ruminants. Reference Book no. 433. London: H. M. Stationery Office.

Oddy, V. H., Brown, B. W. \& Jones, A. W. (1981). Measurement of organ blood flow using tritiated water. I. Hind-limb muscle blood flow in conscious ewes. Australian Journal of Biological Sciences 34, 419-425.

Oddy, V. H., Gooden, J. M. \& Annison, E. F. (1984). Partitioning of nutrients in Merino ewes. I. Contribution of skeletal muscle, the pregnant uterus and the lactating mammary gland to total energy expenditure. Australian Journal of Biological Sciences 37, 375-388.

Oddy, V. H., Jones, A. W. \& Warren, H. M. (1988). Phenylalanine as a marker of muscle protein synthesis. Proceedings of the Nutrition Society of Australia 13, 119.

Oddy, V. H. \& Lindsay, D. B. (1986). Determination of rates of protein synthesis, gain and degradation in intact hind-limb muscle of lambs. Biochemical Journal 233, 417-425.

Oddy, V. H., Lindsay, D. B., Barker, P. J. \& Northrop, A. J. (1987). Effect of insulin on hind-limb and whole body leucine and protein metabolism in fed and fasted lambs. British Journal of Nutrition 58, 437-452.

Ohisalo, J. J., Andersson, B. M., Viljanen, A. A. \& Andersson, S. M. (1982). Is there a brain tyrosine aminotransferase? Biochemical Journal 204, 621-622.

Pacy, P. J., Cheng, K. N., Rennie, M. J. \& Halliday, D. (1988). Muscle protein synthesis rate - a reappraisal of control values. Proceedings of the Nutrition Society 47, $53 \mathrm{~A}$.

Pappenheimer, J. R. \& Setchell, B. P. (1972). The measurement of cerebral blood flow in the rabbit and sheep. Journal of Physiology 226, 48P-50P.

Pell, J. M., Caldarone, E. M. \& Bergman, E. N. (1986). Leucine and $\alpha$-ketoisocaproate metabolism and interconversions in fed and fasted sheep. Metabolism 35, 1005-1016.

Pethick, D. W., Harman, N. \& Chong, J. K. (1987). Non-esterified long chain fatty acid metabolism in fed sheep at rest and during exercise. Australian Journal of Biological Sciences 40, 221-234.

Preedy, V. R., McNurlan, M. A. \& Garlick, P. J. (1983). Protein synthesis in skin and bone of the young rat. British Journal of Nutrition 49, 517-523.

Seve, B., Reeds, P. J., Fuller, M. F., Cadenhead, A. \& Hay, S. M. (1986). Protein synthesis and retention in some tissues of the young pig as influenced by dietary protein intake after early weaning. Possible connection to the energy metabolism. Reproduction, Nutrition, Développement 26, 849-861.

Teleni, E. \& Annison, E. F. (1986). Development of a sheep hind-limb muscle preparation for metabolic studies. Australian Journal of Biological Sciences 39, 271-281.

Teleni, E., Annison, E. F. \& Lindsay, D. B. (1986). Metabolism of valine and the exchange of amino acids across the hind-limb muscles of fed and starved sheep. Australian Journal of Biological Sciences 39, 379-393. 
Thompson, G. N., Pacy, P. J., Merritt, H., Ford, G. C., Read, M. A., Cheng, K. N. \& Halliday, D. (1989). Rapid measurement of whole body and forearm protein turnover using a $\left[{ }^{2} \mathrm{H}_{5}\right]$ phenylalanine model. American Journal of Physiology 256, E631-E639.

Tomas, F. M. \& Ballard, F. J. (1987). Applications of the N-methylhistidine technique for measuring myofibrillar protein breakdown in vivo. In Lysosomes: Their Role in Protein Breakdown, pp. 679-711 [H. Glaumann and F. J. Ballard, editors]. London: Academic Press.

Vincent, R. (1984). Protein metabolism in sheep: measurement in vivo and the effects of pregnancy and lactation. PhD Thesis, University of Cambridge.

Waalkes, T. P. \& Udenfriend, S. (1957). A fluorometric method for the estimation of tyrosine in plasma and tissues. Journal of Laboratory and Clinical Medicine 50, 773-736.

Waterlow, J. C., Garlick, P. J. \& Millward, D. J. (1978). Protein Turnover in Mammalian Tissues and in the Whole Body. London: North-Holland. 